\title{
HUBUNGAN PERAN KELUARGA DAN RELIGIUSITAS DENGAN PERILAKU SEKS PRA NIKAH PADA REMAJA
}

\author{
Dyah Ayu Wulandari ${ }^{1}$ Welia Rahmawati ${ }^{2}$ \\ Progam Studi DIV Bidan Pendidik Sekolah Tinggi Ilmu Kesehatan Karya Husada \\ Semarang
}

Email: tata.talitha@gmail.com

\begin{abstract}
ABSTRAK
Latar Belakang : Hasil survei dari Komisi Nasional Perlindungan Anak dalam Dakosta dkk (2014) terhadap 4.500 remaja di 12 kota besar di Indonesia tahun 2007 menunjukkan, 97\% dari responden pernah menonton film porno, 93,7\% pernah ciuman, petting, dan oral seks, serta $62,7 \%$ remaja yang duduk di bangku SMP pernah berhubungan intim, dan 21,2\% siswi pernah menggugurkan kandungan. Tujuan Penelitian : Untuk mengetahui hubungan peran keluarga dan religiusitas dengan perilaku seks pranikah pada remaja. Metode Penelitian : Jenis penelitian deskriptif analitik dengan desain penelitian menggunakan cross sectional. Populasi dalam penelitian ini adalah siswa dan siswi SMA Muhammadiyah Kudus Kelas XI Tahun Ajaran 2016 / 2017 sebanyak 104 siswa. Besar sampel yang akan digunakan dalam penelitian ini adalah sebanyak 83 siswa. Teknik sampling yang digunakan dalam penelitian ini adalah Proportionet Stratified Random Sampling. Instrumen dalam penelitian ini menggunakan kuesioner. Hasil Penelitian : Peran keluarga sebagian besar adalah baik sebanyak 55 responden $(66,3 \%)$. Religiusitas sebagian besar adalah baik sebanyak 65 responden $(78,3 \%)$. Perilaku seks pranikah sebagian besar adalah ringan sebanyak 80 responden $(96,4 \%)$. Ada hubungan peran keluarga dengan perilaku seks pranikah pada remaja. Ada hubungan religiusitas dengan perilaku seks pranikah pada remaja. Saran : Pihak sekolah dapat bekerjasama dengan instasi kesehatan untuk memberikan penyuluhan mengenai informasi atau bahaya perilaku seks pranikah pada remaja dengan tujuan pembentukan konsep diri remaja yang baik dalam menanggapi fenomena-fenomena negatif keremajaan, seperti pendalaman pengetahuan tentang bahaya seks bebas, pendidikan tentang bagaimana mengambil keputusan yang baik dalam menghadapi berbagai macam masalah keremajaan.
\end{abstract}

Kata kunci $\quad$ : Peran keluarga, religiusitas, perilaku seks pranikah. remaja Daftar Pustaka : $30(2000-2015)$

\section{ABSTRACT \\ THE CORRELATION FAMILY ROLES AND RELIGIOSITY WITH PRANIKAH SEX BEHAVIOR IN ADOLESCENT}

Background : The survey results from the National Commission for Child Protection in Dakosta et al (2014) to 4,500 young people in 12 major cities in Indonesia in 2007 showed that $97 \%$ of respondents had watched porn, 93.7\% had been kissing, petting, and oral sex, as well as $62,7 \%$ of teenagers in junior high school never having sex, and $21.2 \%$ girls never abort. Objective : To determine the role of the family and religiosity relationship with premarital sexual behavior in adolescents. Method : Descriptive research analytical research using cross sectional design. The population in this study were male and female students of SMA Muhammadiyah Kudus Class XI Academic Year 2016/2017 as many as 104 students. The sample size used in this study was of 83 students. The sampling technique used in this study is Proportional Stratified Random Sampling. Instruments in this study using questionnaires. Results : Family roles are mostly good by 55 respondents (66.3\%). Religiosity most are good as much as 65 respondents (78.3\%). Premarital sexual behavior is largely light as much as 80 respondents $(96.4 \%)$. There is a relationship of family roles with premarital sexual behavior in adolescents. There is a relationship of religiosity with premarital sexual behavior in adolescents. Suggestion : The school can 
cooperate with instasi Health to provide counseling regarding the information or the dangers of premarital sexual behavior among adolescents with the goal of establishing adolescent self-concept is good in responding to the phenomena of negative youthfulness, such as deepening of knowledge about the dangers of casual sex, education on how to make good decisions in the face of various problems youthfulness.

Keywords : The role of the family, religiosity, premarital sexual behavior in adolescents

Reference : $30(2000-2015)$

\section{PENDAHULUAN}

Masa remaja atau adolescence merupakan masa yang paling kritis bagi perkembangan pada tahap kehidupan selanjutnya. Di Indonesia batasan remaja tentang pemuda adalah usia 15-24 tahun. Data penduduk Indonesia jumlah penduduk tahun 2010 adalah 237,6 juta jiwa, $26,67 \%$ diantaranya adalah remaja. ${ }^{(1)}$

Berdasarkan data pusat informasi dan layanan remaja (PILAR) di Perkumpulan Keluarga Berencana Indonesia (PKBI) Jateng tahun 2015, pada tahun 2011 tercatat 2.967 remaja yang berkonsultasi ke PILAR dimana sebanyak 821 remaja berkonsultasi tentang permasalahan kesehatan reproduksi dan terdapat 79 kasus kehamilan tidak diinginkan (KTD). Sementara pada tahun 2012, terdapat 63 kasus KTD pada remaja usia termuda 12 tahun. Dan pada tahun 2013 terdapat 64 kasus KTD, 26 kasus terjadi di Semarang. ${ }^{\text {(2) }}$

Hasil survei dari Komisi Nasional Perlindungan Anak dalam Dakosta (2014) terhadap 4.500 remaja di 12 kota besar di Indonesia tahun 2007 menunjukkan, 97\% dari responden pernah menonton film porno, 93,7\% pernah ciuman, petting, dan oral seks, serta $62,7 \%$ remaja yang duduk di bangku SMP pernah berhubungan intim, dan 21,2\% siswi pernah menggugurkan kandungan. Hal tersebut menunjukkan bahwa perilaku seksual remaja saat berpacaran berpengaruh besar pada kasus kehamilan yang tidak diinginkan (KTD) dan berdampak pada remaja untuk melakukan aborsi.Hal ini diperkuat lagi dengan data dari PKBI Jateng tahun 2014, terdapat 67 kasus KTD. Sebagian besar dari mereka berstatus pelajar yang membuat mereka memilih untuk melakukan aborsi karena ingin melanjutkan sekolahnya. ${ }^{(3)}$

Faktor-faktor yang mempengaruhi perilaku seksual pranikah remaja adalah faktor internal yaitu pengetahuan, sikap, pengendalian diri, rasa percaya diri, usia, religiusitas, gaya hidup, aktifitas sosial, dan status perkawinan. Faktor eksternal yaitu kontak dengan sumbersumber informasi, peran keluarga, sosial budaya nilai dan norma sebagai pendukung social untuk perilaku tertentu.

Hasil wawancara saat studi pendahuluan pada tanggal 21 Mei 2016 kepada salah satu guru Bimbingan dan Konseling (BK) SMA Muhammadiyah Kudus, diperoleh informasi bahwa perilaku berpacaran siswa saat ini memang cukup mengkhawatirkan, mereka sudah tidak segan-segan lagi berpegangan tangan dan berangkulan di depan umum (khalayak ramai). Beliau juga menginformasikan bahwa setiap tahunnya ada siswi yang terpaksa dikeluarkan dari sekolah dikarenakan kehamilan pranikah sebagai konsekuensi dari perilaku seksual tersebu. Sekolah Muhammadiyah ini merupakan sekolah berbasis agama dimana sekolah tersebut hampir setiap hari proses bimbingan belajar dikaitkan dengan norma agama sehingga diharapkan kejadian pacaran yang kurang sehat bahkan kejadian hamil diluar nikah tidak terjadi.

Berdasarkan dari studi pendahuluan maka penulis tertarik untuk melakukan penelitian tentang "Hubungan Peran Keluarga dan Religiusitas dengan Perilaku Seks Pranikah pada Remaja di SMA Muhammadiyah Kudus tahun 2016".

\section{TINJAUAN TEORITIS}


Menurut World Health Organization (WHO), remaja adalah suatu masa dimana individu berkembang dari saat pertama kali ia menunjukkan tanda- tanda seksual sekundernya sampai saat ia mencapai kematangan seksual. Individu juga mengalami perkembangan psikologis dan pola identifikasi dari kanak-kanak menjadi dewasa.Selain itu juga terjadi peralihan dari ketergantungan sosial ekonomi yang penuh kepada keadaan yang relatif lebih mandiri. ${ }^{(4)}$

Menurut Sarwono (2010) ${ }^{(3)}$, perilaku seksual adalah segala tingkah laku yang didorong oleh hasrat seksual baik yang dilakukan sendiri, dengan lawan jenis maupun sesama jenis tanpa adanya ikatan pernikahan menurut agama. Menurut Stuart dan Sundeen (1999), perilaku seksual yang sehat dan adaptif dilakukan ditempat pribadi dalam ikatan yang sah menurut hukum. Muta'din (2013) sedangkan perilaku seksual pranikah merupakan perilaku seksual yang dilakukan tanpa melalui proses pernikahan yang resmi menurut hukum maupun menurut agama dan kepercayaan masing-masing. ${ }^{(6)}$

Peran adalah seperangkat tingkah laku yang diharapkan oleh orang lain terhadap seseorang sesuai kedudukannya dalam suatu sistem. Peran merujuk kepada beberapa set perilaku yang kurang lebih bersifat homogen, yang didefinisikan dan diharapkan secara normatif dari seseorang peran dalam situasi sosial tertentu. ${ }^{(7)}$

Religiusitas adalah sikap batin pribadi (personal) setiap manusia dihadapan Tuhan yang sedikit banyak merupakan misteri bagi orang lain, yang mencakup totalitas kedalam pribadi manusia. Religiusitas merupakan perilaku terhadap agama yang berupa penghayatan terhadap nilai-nilai agama yang dapat ditandai tidak hanya melalui ketaatan dalam menjalankan ibadah ritual tetapi juga degan adanya keyakinan, pengalaman, dan pengetahuan mengenai agama yang dianutnya. ${ }^{(8)}$ Mangunwidjaya (2007) menjelaskan bahwa religiusitas dan agama memang tidak dapat dipisahkan. ${ }^{(9)}$

\section{METODE PENELITIAN}

Jenis penelitian yang digunakan adalah korelasi. Desain penelitian ini adalah cross sectional. Populasi dalam penelitian ini adalah siswa dan siswi SMA Muhammadiyah Kudus Kelas XI Tahun Ajaran 2016 / 2017 sebanyak 104 siswa. Besar sampel yang akan digunakan dalam penelitian ini adalah sebanyak 83 siswa. Teknik sampling yang digunakan dalam penelitian ini adalah Proportional Stratified Random Sampling. Instrumen dalam penelitian ini adalah kuesioner peran keluarga, religiusitas dan perilaku seks pranikah.

Analisa Univariat adalah analisa yang dilakukan terhadap variable dari hasil penelitian, pada umumnya analisa ini hanya menghasilkan distribusi dan presentasi dari setiap variabel. ${ }^{(3)}$ Pada penelitian ini variabel independennya adalah peran keluarga, religiusitas dan variabel dependennya adalah perilaku seks pranikah pada remaja.

Analisa Bivariat merupakan analisa yang dilakukan lebih dari dua variabel, analisa bivariat berfungsi untuk mengetahui hubungan antara variabel independen yaitu peran keluarga dan religiusitas dengan perilaku seks pranikah, dengan menggunakan uji statistic Fisher's Exact Test. ${ }^{(3)}$

\section{HASIL PENELITIAN}




\section{A. Hasil Penelitian}

1. Analisis Univariat

a. Peran keluarga remaja di SMA Muhammadiyah Kudus tahun 2016

Tabel 1 Distribusi frekuensi responden berdasarkan peran keluarga remaja di SMA Muhammadiyah Kudus tahun 2016

\begin{tabular}{ccc}
\hline Peran keluarga & Frekuensi & Persentase \\
\hline Kurang baik & 28 & 33,7 \\
Baik & 55 & 66,3 \\
Jumlah & $\mathbf{8 3}$ & $\mathbf{1 0 0}$ \\
\hline
\end{tabular}

Berdasarkan tabel 4.1 dapat diketahui bahwa peran keluarga sebagian besar adalah baik sebanyak 55 responden $(66,3 \%)$ dan kurang baik sebanyak 28 responden $(33,7 \%)$.

b. Religiusitas remaja di SMA Muhammadiyah Kudus tahun 2016

Tabel 2 Distribusi frekuensi responden berdasarkan religiusitas remaja di SMA Muhammadiyah Kudus tahun 2016

\begin{tabular}{ccc}
\hline Religiusitas & Frekuensi & Persentase \\
\hline Kurang baik & 18 & 21,7 \\
Baik & 65 & 78,3 \\
Jumlah & $\mathbf{8 3}$ & $\mathbf{1 0 0}$ \\
\hline
\end{tabular}

Berdasarkan tabel 4.2 dapat diketahui bahwa religiusitas sebagian besar adalah baik sebanyak 65 responden $(78,3 \%)$ dan kurang baik sebanyak 18 responden $(21,7 \%)$.

c. Perilaku seks pranikah remaja di SMA Muhamadiyah Kudus tahun 2016

Tabel 3 Distribusi frekuensi responden berdasarkan perilaku seks pranikah remaja di SMA Muhamadiyah Kudus tahun 2016

\begin{tabular}{ccc}
\hline Perilaku seks pranikah & Frekuensi & Persentase \\
\hline Ringan & 80 & 96,4 \\
Sedang & 3 & 3,6 \\
\hline Jumlah & $\mathbf{8 3}$ & $\mathbf{1 0 0}$ \\
\hline
\end{tabular}

Berdasarkan tabel 4.3 dapat diketahui bahwa perilaku seks pranikah sebagian besar adalah ringan sebanyak 80 responden $(96,4 \%)$ dan sedang sebanyak 3 responden $(3,6 \%)$.

2. Analisis Bivariat

a. Hubungan peran keluarga dengan perilaku seks pranikah pada remaja di SMA Muhammadiyah Kudus tahun 2016

Tabel 4 Hubungan peran keluarga dengan perilaku seks pranikah pada remaja di SMA Muhammadiyah Kudus tahun 2016 


\begin{tabular}{ccccccccc}
\hline \multirow{2}{*}{ Peran keluarga } & \multicolumn{9}{c}{ Perilaku seks pranikah } & \multirow{2}{*}{ Total } & \multirow{2}{*}{ Pvalue } \\
\cline { 2 - 5 } & \multicolumn{2}{c}{ Ringan } & \multicolumn{2}{c}{ Sedang } & & & \\
\cline { 2 - 6 } & f & $\mathbf{\%}$ & $\mathbf{f}$ & $\mathbf{\%}$ & & & \\
\hline Kurang baik & 25 & 89,3 & 3 & 10,7 & 28 & 100 & 0,036 \\
Baik & 55 & 100 & 0 & 0 & 55 & 100 & \\
\hline Jumlah & $\mathbf{8 0}$ & $\mathbf{9 6 , 4}$ & $\mathbf{3}$ & $\mathbf{3 , 6}$ & $\mathbf{8 3}$ & $\mathbf{1 0 0}$ & \\
\hline
\end{tabular}

Tabel 4 menunjukkan bahwa peran keluarga yang kurang baik sebanyak 28 responden, dengan perilaku seks pranikah sebagian besar adalah ringan sebanyak 25 responden $(89,3 \%)$ dan sedang sebanyak 3 responden $(10,7 \%)$. Peran keluarga yang baik sebanyak 55 responden, dengan perilaku seks pranikah adalah ringan sebanyak 55 responden (100\%).

Hasil uji statistik didapatkan Pvalue $=0,036$, dapat disimpulkan bahwa ada hubungan peran keluarga dengan perilaku seks pranikah pada remaja di SMA Muhammadiyah Kudus tahun 2016.

b. Hubungan religiusitas dengan perilaku seks pranikah pada remaja SMA Muhammadiyah Kudus tahun 2016

Tabel 5 Hubungan religiusitas dengan perilaku seks pranikah pada remaja SMA Muhammadiyah Kudus tahun 2016

\begin{tabular}{ccccccccc}
\hline \multirow{2}{*}{ Religiusitas } & \multicolumn{2}{c}{ Perilaku seks pranikah } & Total & \% & \multirow{2}{*}{ Pvalue } \\
\cline { 2 - 5 } & \multicolumn{2}{c}{ Ringan } & \multicolumn{2}{c}{ Sedang } & & & \\
\cline { 2 - 5 } & $\mathbf{f}$ & $\mathbf{\%}$ & $\mathbf{f}$ & $\mathbf{\%}$ & & & \\
\hline Kurang baik & 15 & 83,3 & 3 & 16,7 & 18 & 100 & 0,009 \\
Baik & 65 & 100 & 0 & 0 & 65 & 100 & \\
\hline Jumlah & $\mathbf{8 0}$ & $\mathbf{9 6 , 4}$ & $\mathbf{3}$ & $\mathbf{3 , 6}$ & $\mathbf{8 3}$ & $\mathbf{1 0 0}$ & \\
\hline
\end{tabular}

Tabel 5 menunjukkan bahwa religiusitas yang kurang baik sebanyak 18 responden, dengan perilaku seks pranikah sebagian besar adalah ringan sebanyak 25 responden $(83,3 \%)$ dan sedang sebanyak 3 responden $(16,7 \%)$. Religiusitas yang baik sebanyak 65 responden, dengan perilaku seks pranikah adalah ringan sebanyak 65 responden (100\%).

Hasil uji statistik didapatkan Pvalue $=0,009$, dapat disimpulkan bahwa ada hubungan religiusitas dengan perilaku seks pranikah pada remaja di SMA Muhammadiyah Kudus tahun 2016.

\section{B. Pembahasan}

1. Analisis Univariat

a. Peran keluarga remaja di SMA Muhammadiyah Kudus tahun 2016

Hasil penelitian dapat diketahui bahwa peran keluarga sebagian besar adalah baik sebanyak 55 responden $(66,3 \%)$. Semakin tinggi peran keluarga pada remaja, maka perilaku seksual remaja semakin baik. Informasi atau pengetahuan mengenai seksualitas yang diberikan pada remaja lebih baik dan tepat jika dilakukan dalam keluarga, karena anak dilahirkan dan dibesarkan dalam lingkungan keluarga, sehingga cara lain yang dapat diusahakan untuk mengurangi perilaku seksual pranikah pada remaja adalah dengan meningkatkan kualitas komunikasi orang tua dengan anaknya. ${ }^{(10)}$ 
Hasil penelitian juga didapatkan peran keluarga kurang baik sebanyak 28 responden $(33,7 \%)$. Hal ini didukung jawaban responden pada pertanyaan orang tua saya merespon dengan baik setiap pertanyaan / pernyataan yang menyangkut seks sebanyak 45 responden $(54,2 \%)$. Apakah orang tua anda mengajarkan tentang perilaku seks menyimpang dan resikonya agar anda tidak melakukannya sebanyak 17 responden $(20,5 \%)$. Peran keluarga disini hanya memberitahu saja tanpa memberi kesempatan untuk berbicara secara terbuka maupun berdiskusi tentang apa yang terjadi atau yang sedang dialami oleh remaja. Kurangnya pemberian informasi secara terbuka antara orang tua dengan remaja dalam masalah seksual dapat memperkuat munculnya penyimpangan perilaku seksual.

Menurut Priyonggo (2010) orang tua yang tidak lagi dianggap sebagai tempat yang aman dan mampu melindungi anggota keluarganya akan menimbulkan persoalan-persoalan yang semakin pelik pada anak, salah satunya yaitu masalah perilaku seksual pranikah, sehingga peran orang tua sangat diperlukan dalam memberikan informasi dan bimbingan tentang seksualitas kepada remaja. ${ }^{(11)}$

Hasil penelitian ini sesuai dengan penelitian yang dilakukan oleh Sesa (2013) dengan judul : Hubungan peran orang tua dan sumber informasi dengan perilaku seksual remaja di SMAN 15 Semarang. Peran orang tua sebagian besar cukup sebanyak 88 responden $(57,7 \%){ }^{(12)}$

b. Religiusitas remaja di SMA Muhammadiyah Kudus tahun 2016

Hasil penelitian dapat diketahui bahwa religiusitas sebagian besar adalah baik sebanyak 65 responden (78,3\%). Religiusitas ditunjukkan melalui ibadah keagamaan, seperti menjalankan nilai-nilai agama dan menghindari perilakuperilaku yang dilarang oleh ajaran agamanya. Perilaku yang diatur oleh tuntutan agama akan mengarahkan seseorang dalam mengendalikan dirinya. Religiusitas memiliki peranan yang sangat kuat terhadap kehidupan seseorang, sebab di dalamnya telah terkandung berbagai dimensi kehidupan manusia (Ancok \& Suroso, 2010).

Hasil penelitian juga didapatkan religiusitas kurang baik sebanyak 18 responden $(21,7 \%)$. Hal ini didukung jawaban responden pada pertanyaan : Melaksanakan ibadah merupakan salah satu cara untuk meningkatkan ketakwaan kepada Tuhan Yang Maha Esa sebanyak 29 responden (34,9\%).

Remaja akhir yang terlibat dalam kehidupan seksual secara bebas menunjukkan bahwa mereka tidak mampu mengendalikan diri karena keyakinan religiusnya rendah. Ketidakmampuan remaja dalam mengendalikan diri inilah yang dapat menimbulkan kecenderungan perilaku seksual pranikah sehingga berdampak negatif seperti kehamilan yang tidak diinginkan (KTD). ${ }^{(13)}$

Faktor-faktor yang mempengaruhi perilaku seksual pranikah mengungkapkan bahwa remaja yang memiliki keyakinan yang kuat terhadap ajaran agamanya akan memiliki tolak ukur tentang apa yang boleh atau tidak boleh dilakukan. Ia cenderung akan menghindari hal-hal atau situasi yang dapat memunculkan dorongan seksual yang kuat. Ia akan mudah untuk berkata tidak atau menolak untuk melakukan perilaku-perilaku yang dilarang oleh agamanya. ${ }^{(4)}$

Menurut Gunarsa (2009) kontrol diri berfungsi membatasi individu untuk bertingkah laku negatif. Individu yang memiliki pengendalian diri akan terhindar dari berbagai tingkah laku negatif. Pengendalian diri memiliki arti sebagai kemampuan individu menahan dorongan atau keinginan untuk bertingkah laku negatif yang tidak sesuai dengan norma sosial. ${ }^{(14)}$ 
Hasil penelitian sesuai dengan penelitian yang dilakukan oleh Aini (2011) dengan judul : Hubungan pemahaman tingkat agama (religiusitas) dengan perilaku seks bebas pada remaja di SMAN 1 Bangsal Mojokerto. Hasil penelitian menunjukkan sebagian besar pemahaman tingkat agama adalah kategori baik $(38,7 \%){ }^{(15)}$

c. Perilaku seks pranikah remaja di SMA Muhamadiyah Kudus tahun 2016

Hasil penelitian dapat diketahui bahwa perilaku seks pranikah sebagian besar adalah ringan sebanyak 80 responden (96,4\%). Pada seorang remaja, perilaku seksual pranikah tersebut dapat dipengaruhi oleh rasa cinta dengan dominasi perasaan kedekatan yang tinggi terhadap pasangannya, tanpa disertai komitmen yang jelas atau karena pengaruh kelompok. Dimana remaja tersebut ingin menjadi bagian dari kelompoknya dengan mengikuti kebiasaan-kebiasaan yang telah dianut oleh kelompoknya.

Hasil penelitian juga didapatkan perilaku seks pranikah sedang sebanyak 3 responden $(3,6 \%)$. Hal ini didukung jawaban responden pada pertanyaan : Apakah anda pernah berciuman bibir dengan pasangan anda sebanyak 66 responden $(79,5 \%)$. Saya memegang paha pacar, ketika sedang berboncengan sepeda motor sebanyak 80 responden $(96,4 \%)$.

Pada masa remaja kedekatanya dengan teman sebaya sangat tinggi karena selain ikatan teman sebaya menggantikan ikatan keluarga, mereka juga merupakan sumber afeksi, simpati, pengertian, saling berbagi pengalaman dan sebagai tempat remaja untuk mencapai otonom. ${ }^{(16)}$

Akibat globalisasi pandangan remaja terhadap perilaku seksual pranikah mengalami pergeseran. Globalisasi peradaban telah mengakibatkan terbentuknya kultur dan gaya hidup, terutama pada kaum muda suatu kelompok usia yang sangat rawan terhadap berbagai perubahan dan pengaruh yang datang dari luar. Dimana ketika hubungan seksual dibelahan dunia lain mengalami penurunan nilai sakral dan penurunan nilai moral, maka persepsi tersebut membentuk persepsi serupa dibelahan dunia lainnya. Karena itu, hubungan seksual pranikah saat ini menjadi gejala umum yang terasa kian sulit dibentengi dengan penyadaran moral dan agama. ${ }^{(17)}$

Didukung penelitian Sesa (2013) dengan judul : Hubungan peran orang tua dan sumber informasi dengan perilaku seksual remaja di SMAN 15 Semarang. Perilakus seks sebagian besar cukup sebanyak 68 responden $(44,4 \%){ }^{(12)}$

2. Analisis Bivariat

a. Hubungan peran keluarga dengan perilaku seks pranikah pada remaja di SMA Muhammadiyah Kudus tahun 2016

Hasil penelitian didapatkan Pvalue $=0,036$, dapat disimpulkan bahwa ada hubungan peran keluarga dengan perilaku seks pranikah pada remaja di SMA Muhammadiyah Kudus tahun 2016.

Peran keluarga yang kurang baik sebanyak 28 responden, dengan perilaku seks pranikah sebagian besar adalah ringan sebanyak 25 responden $(89,3 \%)$, dari data tersebut dapat dilihat bahwa peran keluarga kurang baik tetapi perilaku seks pra nikah ringan dikarenakan seringkali remaja merasa bahwa orang tuanya menolak membicarakan masalah perilaku seks pranikah sehingga mereka kemudian mencari alternatif sumber informasi lain seperti teman atau media massa. Teman-teman yang tidak baik berpengaruh terhadap munculnya perilaku seks pra nikah, sehingga informasi yang baik dan akurat diperlukan oleh remaja untuk menghindari pengaruh buruk yang dapat menimbulkan perilaku seksual pra nikah. 
Peran keluarga yang baik sebanyak 55 responden, dengan perilaku seks pranikah adalah ringan sebanyak 55 responden (100\%). Orang tua adalah tokoh penting dalam perkembangan identitas remaja. Dalam hal komunikasi orang tua dengan remaja, seharusnya dapat dibina terus menerus, sehingga orang tua dapat mengetahui hal- hal yang berhubungan dengan tahap perkembangan remaja, dan remaja juga mendapatkan pemenuhan kebutuhan jasmani dan rohaninya. Remaja akan terhindar dari keterlibatan dengan seks pranikah, jika remaja dapat membicarakan masalah seks dengan orang tuanya. Artinya, orang tua menjadi pendidik seksualitas bagi anak remajanya. ${ }^{(16)}$

Menurut Soetjiningsih (2009) menunjukkan makin baik hubungan orang tua dengan anak remajanya, makin rendah perilaku seksual pranikah remaja. Faktor-faktor yang mempengaruhi perilaku seksual pranikah pada remaja paling tinggi adalah hubungan antara orang tua dengan remaja, tekanan teman sebaya, pemahaman tingkat agama (religiusitas), dan eksposur media pornografi.

Didukung Kothari (2011) mengatakan informasi tentang seks yang tidak benar diterima oleh remaja selalu memberikan efek negatif, artinya remaja lebih banyak mengetahui masalah seksual melalui televisi merangsang para remaja lebih penasaran dan ingin tahu setelah mengakses informasi bahkan selalu mencobacoba. Media televisi menyediakan gambar atau film porno yang memberikan reaksi negatif untuk merangsang para remaja dalam merespon seksual. ${ }^{(18)}$

Didukung penelitian Sesa (2013) dengan judul : Hubungan peran orang tua dan sumber informasi dengan perilaku seksual remaja di SMAN 15 Semarang $($ Pvalue $=0,000){ }^{(9)}$

b. Hubungan religiusitas dengan perilaku seks pranikah pada remaja SMA Muhammadiyah Kudus tahun 2016

Hasil penelitian didapatkan Pvalue = 0,009 dapat disimpulkan bahwa ada hubungan religiusitas dengan perilaku seks pranikah pada remaja di SMA Muhammadiyah Kudus tahun 2016.

Religiusitas yang kurang baik sebanyak 18 responden, dengan perilaku seks pranikah sebagian besar adalah ringan sebanyak 25 responden $(83,3 \%)$, dari data tersebut dapat dilihat bahwa religiusitas kurang baik tetapi perilaku seks pranikah sedang karena perilaku religiusitas tidak didasari pemahaman filosofi atau belive yang terkandung dalam kaidah-kaidah agama,mereka melakukan keberagamaan bukan atas dasar kepercayaan yang kuat terhadap agamanya, melainkan karena semata-mata akan mendapat pahala atau dosa.

Berdasarkan penelitian yang dilakukan oleh Nugrahawati (2011) pemahaman tingkat agama menunjukkan bahwa kemampuan remaja dalam memahami dan mengetahui tentang agama. Oleh karena itu, masalah komitmen beragama atau religiusitas adalah masalah yang sangat individual dan pribadi. Dengan demikian, remaja sangat perlu meningkatkan keimanan dan ketaqwaan mereka sesuai dengan agama yang dianutnya, karena pemahaman agama yang dimiliki remaja dapat juga mempengaruhi mereka dalam berperilaku. ${ }^{(19)}$

Religiusitas yang baik sebanyak 65 responden, dengan perilaku seks pranikah adalah ringan sebanyak 65 responden (100\%). Pemahaman tingkat agama yang baik menghasilkan tauhid dan kepercayaan terhadap remaja untuk menghindari perilaku yang menyimpang. Remaja yang religiusitasnya tinggi menunjukkan perilaku terhadap hubungan seksual bebas rendah (menolak), sedangkan remaja yang religiusitasnya rendah menunjukkan perilaku terhadap hubungan seksual bebas tinggi (menerima). 
Agama itu sebenarnya adalah pendidikan, dan ajaran agama dapat dikatakan alat pendidikan yang bisa mengubah tingkah laku manusia kearah yang diinginkan atau diridhoi Tuhan. Tingkah laku yang perlu ditumbuhkan kepada remaja ialah berbuat sesuatu adalah karena Tuhan, karena keinginan Tuhan, karena mengharapkan ridha Tuhan semata. Kuat lemahnya motif karena Tuhan amat banyak bergantung kepada situasi lingkungan. Jika pengaruh-pengaruh negatif lebih dominan, maka motif berbuat karena Tuhan akan dikalahkan. ${ }^{(20)}$

Religiusitas merupakan penghayatan agama seseorang yang menyangkut simbol, keyakinan, nilai dan perilaku yang didorong oleh kekuatan spiritual. Untuk mengukur religiusitas ada tiga dimensi dalam Islam yaitu, aspek akidah (keyakinan), aspek syariah (praktik agama, ritual formal), dan aspek akhlak (pengamalan dari akidah dan syariah). ${ }^{(21)}$

Pemahaman adalah suatu proses, cara memahami cara mempelajari baikbaik supaya paham dan pengetahuan banyak. Pengertian pemahaman mencakup tujuan, tingkah laku, atau tanggapan mencerminkan sesuatu pemahaman pesan tertulis yang termuat dalam satu komunikasi. Pemahaman dapat dibedakan kedalam 3 kategori yaitu, tingkat terendah adalah pemahaman terjemahan, mulai dari menerjemahkan dalam arti yang sebenarnya, mengartikan dan menerapkan prinsip-prinsip, tingkat kedua adalah pemahaman penafsiran yaitu menghubungkan bagian-bagian terendah dengan yang diketahui berikutnya atau menghubungkan beberapa bagian grafik dengan kejadian, membedakan yang pokok dengan yang tidak pokok. ${ }^{(22)}$

Menurut Adawiyah (2007) dari hasil penelitiannya ada perbedaan yang sangat signifikan antara perilaku dengan hubungan seksual pranikah antara remaja yang religiusitasnya tinggi dengan remaja yang religiusitasnya rendah. Pemahaman agama yang baik akan menumbuhkan perilaku yang baik. Remaja memerlukan kemampuan pemecahan masalah yang baik, sehingga remaja mampu menyelesaikan masalah mereka dengan efektif. Orang tua perlu memberikan bekal materi, intelektual yang berupa pendidikan formal, serta bekal spiritual yang berupa pendidikan agama bagi remaja. ${ }^{(23)}$

Faktor lain yang memengaruhi perilaku seksual pranikah pada remaja adalah pengaruh media massa yang sering kali diimitasi oleh remaja dalam perilakunya sehari-hari. (4) Misalnya saja remaja yang menonton film berkebudayaan barat, mereka melihat perilaku seks itu menyenangkan dan dapat diterima lingkungan. Hal ini pun diimitasi oleh mereka, terkadang tanpa memikirkan adanya perbedaan kebudayaan, nilai, serta norma-norma dalam lingkungan masyarakat yang berbeda.

Didukung penelitian Aini (2011) hasil penelitian menunjukkan bahwa ada hubungan pemahaman tingkat agama (religiusitas) dengan perilaku seks bebas pada remaja di SMAN 1 Bangsal Mojokerto (Pvalue $=0,000) .{ }^{(15)}$

\section{SIMPULAN DAN SARAN}

\section{A. Kesimpulan}

Perilaku seks pranikah pada remaja di SMA Muhammadiyah Kudus tahun 2016 dipengaruhi oleh Peran keluarga dan Religiusitas. 


\section{B. Saran}

1. Bagi Instansi Kesehatan Puskesmas wilayah Damaran

Instansi Kesehatan dan instansi terkait untuk perbaikan perencanaan maupun implementasi program,dengan mengadakan penyuluhan di instasi pendidikan tentang bahaya seks pranikah khususnya bagi para remaja.

2. Bagi Sekolah SMA Muhammadiyah Kudus

Pihak sekolah dapat bekerjasama dengan instasi kesehatan untuk memberikan penyuluhan mengenai informasi atau bahaya perilaku seks pranikah pada remaja dengan tujuan pembentukan konsep diri remaja yang baik dalam menanggapi fenomena-fenomena negatif keremajaan, seperti pendalaman pengetahuan tentang bahaya seks bebas, pendidikan tentang bagaimana mengambil keputusan yang baik dalam menghadapi berbagai macam masalah keremajaan,dilakukan tiap semester sekali.

3. Bagi Siswa

Remaja dapat lebih selektif dan mengontrol diri agar tidak terpengaruh oleh media yang memberikan informasi negatif tentang perilaku seks bebas, agar tidak terjerumus kedalam perilaku seks pranikah. Hendaknya para remaja yang menjalin hubungan(pacaran) di lakukan secara sehat.

4. Bagi Orang Tua

Orang tua agar dapat melakukan langkah-langkah yang lebih lanjut dan bermanfaat dalam proses pembentukan kepribadian anak. Selain itu dapat digunakan sebagai acuan cara membina perilaku anak terutama dari keluarga yang tidak harmonis dalam menjalin hubungan dengan anak-anaknya atau hubungan sosial masyarakat.

5. Bagi Peneliti Selanjutnya

Peneliti selanjutnya agar meneliti dengan faktor lain yang berhubungan dengan perilaku seks pranikah serta dengan metode kualitatif atau wawancara secara mendalam.

\section{DAFTAR PUSTAKA}

1. BKKBN. 2011. Informasi Dasar Penanggulangan Masalah Kesehatan Reproduksi. BKKBN : Jakarta. Diakses tanggal 26 April 2016.

2. PILAR PKBI Jawa Tengah. 2015. Remaja Butuh Akses Layanan Kesehatan Reproduksi Yang Ramah. Semarang : Devisi Layanan PILAR.

3. Notoatmodjo, S. 2010. Pendidikan dan Perilaku Kesehatan. Jakarta : Rineka Cipta.

4. Sarwono, W, S. 2011. Psikologi Remaja. Jakarta: PT. Rajawali Grafindo Persada.

5. Sarwono, W, S. 2013. Psikologi Remaja. Jakarta : Rajawali Pers.

6. Mu'tadin, Z. 2013. Pendidikan Seksual Pada Remaja. Yogyakarta : Nuha Medika.

7. Mubarak, I.W., Chayatin, N \& Santoso, A.B. 2009. Ilmu Keperawatan Komunitas: Konsep dan Aplikasi. Jakarta: Penerbit Salemba Medika.

8. Ancok, D. \& Suroso, F. N. 2011. Psikologi Islami: Solusi Islam atas Problem-problem Psikologi. Yogyakarta : Pustaka Pelajar.

9. Mangunwijaya, Y. B. 2007. Menumbuhkan Sikap Religiusitas Anak. Jakarta : Gramedia.

10. Maesaroh. 2010. Faktor-faktor yang berhubungan dengan perilaku seks pranikah pada remaja di desa Pageruyung Kabupaten Kendal. Unika Kendal. Skripsi tidak dipublikasikan.

11. Priyonggo. 2010. Penting, komunikasi dalam keluarga. Jakarta : Suara Merdeka.

12. Sesa, J.J. 2013. Hubungan peran orang tua dan sumber informasi dengan perilaku seksual remaja di SMAN 15 Semarang. Skripsi tidak dipublikasikan.

13. Dariyo, A. 2009. Psiklogi Perkembangan Remaja. Bogor: Ghalia Indonesia. 
14. Gunarsa, S. 2009. Dari anak sampai usia lanjut: Bunga Rampai Psikologi Perkembangan. Jakarta : PT BPK Gunung Mulia.

15. Aini, N.L. 2011. Hubungan pemahaman tingkat agama (religiusitas) dengan perilaku seks bebas pada remaja di SMAN 1 Bangsal Mojokerto. Skripsi tidak dipublikasikan.

16. Soetjiningsih. 2009. Buku Ajar : Tumbuh Kembang Remaja dan Permasalahannya. Jakarta : Sagung Seto.

17. Mayasari. 2008. Seksualitas remaja. Yogyakarta: Pusat Penelitian Kependudukan UGM dan Ford Foundation.

18. Kothari, P. 2011. Sexual problem and solution. Jakarta : PT Gramedia Pustaka Utama.

19. Nugrahawati, N. 2011. Profil teman sebaya, religiusitas dan perilaku seksual pranikah pada mahasiswa. Yogyakarta : Nuha Medika.

20. Jalaluddin. 2008. Psikologi Agama. Jakarta : Pustaka Pelajar.

21. Andisti, M. A., \& Ritandiyono. 2008. Religiusitas dan Perilaku Seks Bebas pada Dewasa Awal. Jurnal Psikologi.

22. Dister, N. S. 2008. Pengantar Psikologi Agama : Pengalaman dan Motivasi Beragama. Jakarta : Leppenas.

23. Adawiyah R. 2007. Perbedaan Perilaku Terhadap Hubungan Seksual Pranikah Ditinjau Dari Religiusitas. http://etd.library.ums.ac.id/go.php?id=jtptums-gdl-s1-2007-rabiatulad5614. Diakses pada tanggal 15 Januari 2017. 